\title{
IMPLEMENTASI SISTEM BACKUP DATA PADA SISTEM INFORMASI PERPUSTAKAAN UNIVERSITAS PENDIDIKAN GANESHA
}

\author{
Kadek Surya Mahedy \\ UPT TIK Universitas Pendidikan Ganesha \\ Email:surya.mahedy@undiksha.ac.id
}

\begin{abstract}
ABSTRAK
Pada sistem informasi perpustakaan Universitas Pendidikan Ganesha, terdapat basis data yang tersimpan pada server sistem informasi. Basis data ini dapat diakses secara online oleh civitas akademika Universitas Pendidikan Ganesha, beberapa faktor teknis terkadang membuat sistem database mengalami kerusakan atau kehilangan data, hal ini dapat disebabkan secara hardware maupun secara software, salah satu cara untuk mengamankan data tersebut adalah dengan mengimplementasikan bebrapa metode sistem backup data. Penelitian ini bertujuan untuk melakukan backup terhadap basis data sistem informasi perpustakaan dan melakukan backup file web sistem informasi perpustakaan. Sistem ini dikembangkan dengan metode prototyping dengan beberapa tahapan yaitu: 1. Pengumpulan kebutuhan 2. Membangun prototyping (model) 3. Evaluasi prototyping 4. Mengkedokan sistem 5. Melakukan pengujian sistem 6. Evaluasi sistem 7. Implementasi dan penggunaan sistem. Hasil dari penelitian ini adalah sebuah sistem yang dapat melakukan backup database sistem informasi perpustakaan secara full backup otomatis dan melakukan backup file web sistem informasi perpustakaan secara mirror backup.
\end{abstract}

Kata Kunci: backup, mirros dan server

\begin{abstract}
In the Ganesha Education University library information system, there is a database stored on the information system server. This database can be accessed online by the academic community of Universitas Pendidikan Ganesha, some technical factors sometimes cause the database system to suffer damage or loss of data, this can be caused by hardware or software, one way to secure the data is to implement several system methods. data backup. This research aims to back up the library information system database and back up the library information system web files. This system developed using the prototyping method with several stages namely: 1. Gathering requirements 2. Building prototyping (model) 3 . Evaluation of prototyping 4 . Impersonating the system 5. Performing system testing 6 . Evaluation of the system 7. System implementation and system usage. The result of this research are a system database in full automatic back up and back up the library information system web files by mirror back up.
\end{abstract}

Keywords: backup, mirrors and server 


\section{PENDAHULUAN}

Penerapan Teknologi Informasi (TI) saat ini telah menyebar hampir di semua bidang tidak terkecuali di perpustakaan. Perpustakaan menurut pasal 1 Undang-Undang nomor 43 tahun 2003 adalah suatu institusi pengelola koleksi karya ilmiah, karya cetak, dan atau karya rekam secara professional dengan sistem yang baku, guna memenuhi kebutuhan pendidikan, penelitian, pelestarian, informasi dan rekreasi para pemustaka. Kebutuhan akan TI sangat berhubungan dengan peran dari perpustakaan sebagai kekuatan dalam pelestarian dan penyebaran informasi ilmu pengetahuan dan kebudayaan. Sistem Informasi Perpustakaan Universitas Pendidikan Ganesha memberikan layanan kepada pemustaka secara online. Database merupakan aspek yang sangat penting dalam sistem informasi layanan perpustakaan. Database perpustakaan berfungsi sebagai media penyimpanan data yang memungkian pengguna untuk mengolah kembali data dan informasi yang dibutuhkan dalam layanan perpustakaan. Database perpustakaan menyimpan data koleksi buku, data koleksi audio visual, data koleksi karya ilmiah mahasiswa, data koleksi jurnal, data keanggotaan, data kunjungan, data transaksi sirkulasi (peminjaman dan pengembaian buku) serta file karya ilmiah mahasiswa. Tabel dibawah ini menunjukkan jumlah data pada basis data perpustakaan.

Tabel 1. Jumlah Data Pada Basis Data Perpustakaan

\begin{tabular}{clc}
\hline No & \multicolumn{1}{c}{ Jenis Data } & Jumlah/Satuan \\
\hline 1 & Koleksi Buku & $14037 /$ record \\
2 & Koleksi Jurnal & $2834 /$ record \\
3 & Koleksi Audio Visual & $726 /$ record \\
4 & Karya ilmiah mahasiswa & $10951 /$ record \\
5 & Kunjungan & $134664 /$ record \\
6 & Transaksi sirkulasi & $60936 /$ record \\
5 & Keanggotaan & $11777 /$ record \\
6 & File karya ilmiah & $19945 /$ file \\
\hline
\end{tabular}

(sumber : admin sistem informasi perpustakaan)

Perpustakaan sebagai institusi pengelola informasi tidak bisa terlepas dari data yang tersimpan pada database server. Di dalam sistem database, kemungkinan terjadinya gangguan kerusakan server selalu ada. Gangguan atau bahaya yang mengakibatkan kerusakan server terbagi menjadi dua yaitu internal dan eksternal. Gangguan atau bahaya internal meliputi faktor keteledoran manusia dan kerusakan sistem, seperti sistem crash dan akibat dari ganguan listrik yang dapat mengakibatkan hilangnya informasi yang ada dimemori utama dan register. Sedangkan bahaya eksternal adanya bencana alam seperti kebakaran, gempa bumi dan banjir. Kerusakan (crass) pada server maupun database mengakibatkan gangguan pada kinerja web server. Gangguan ini mengakibatkan web server tidak bisa aktif sebagaimana mestinya sehingga sistem layanan dan informasi web perpustakaan Undiksha tidak bias diakses. Gangguan yang sering terjadi adalah gangguan internal seperti ketidaksetabilan listrik. Keadaan ini bisa berpengaruh pada infrastruktur hardware dan software dalam sistem jaringan, penanganan yang dilakukan adalah dengan mengupdate sistem dan recovery sistem database. Pada saat melakukan recovery diperlukan diperlukan backup data. Jika backup data tidak sempurna maka recovery sistem tidak akan berjalan sempurna. Menghadapi permasalahan diatas dan untuk menjaga keamanan data pada server maka perlu dikembangkan metode backup database secara otomatis. Database backup secara otomatis adalah teknik menyalin data ke dalam media lain secara terjadwal. Data yang berada pada primary database (utama) disalin ke dalam secondary database (cadangan) secara terjadwal. Jika primary database mengalami kerusakan maka data tetap aman di dalam secondary database. Dan secondary database akan mengembalikan (restore) data apabila primary database sudah siap untuk digunakan kembali. 
Sesuai dengan uraian latar belakang masalah, maka permasalahan yang akan dibahas yaitu: Bagaimana sistem backup database sistem informasi perpustakaan secara otomatis dengan metode backup penuh (full backup) dan backup file web sistem informasi perpustakaan secara otomatis dengan metode cermin (mirror backup) ?

Tujuan yang ingin dicapai dari penelitian ini adalah: Backup database sistem informasi perpustakaan secara otomatis dengan metode backup penuh (full backup) dan file backup sistem informasi perpustakaan secara otomatis dengan metode cermin (mirror backup) untuk keamanan data dari kerusakan dan pencurian.

\section{METODE}

Penelitian ini merupakan pengembangan perangkat lunak, dengan sasaran akhir yang diharapkan adalah sistem backup database otomatis pada sistem informasi Perpustakaan Undiksha dengan metode backup penuh (full backup) dan backup file web otomatis pada sistem informasi Perpustakaan Undiksha metode cermin (mirror backup). Metode yang digunakan dalam penelitian yakni paradigma prototyping. Prototyping merupakan sebuah proses yang memungkinkan pengembang untuk membuat model perangkat lunak yang akan direkayasa. Pada pengembangan perangkat lunak dengan paradigma prototyping, memungkinkan pengembang untuk membentuk prototipe awal program. Dengan prototipe tersebut maka pengembang dapat menyesuaikan rancangan program dengan kebutuhan pemakai dan pemakai mendapat gambaran awal mengenai perangkat lunak yang dibuat. Dengan demikian pemakai dapat mengoreksi rancangan yang telah dibuat apakah sudah sesuai dengan yang diharapkan atau masih ada kekurangan. Kelebihan paradigma ini adalah terjadi kesesuaian antara permintaan pemakai dengan rancangan yang dibuat oleh pengembang dengan lebih cepat. Urutan langkah pada paradigma prototyping diilustrasikan dalam gambar di bawah ini.

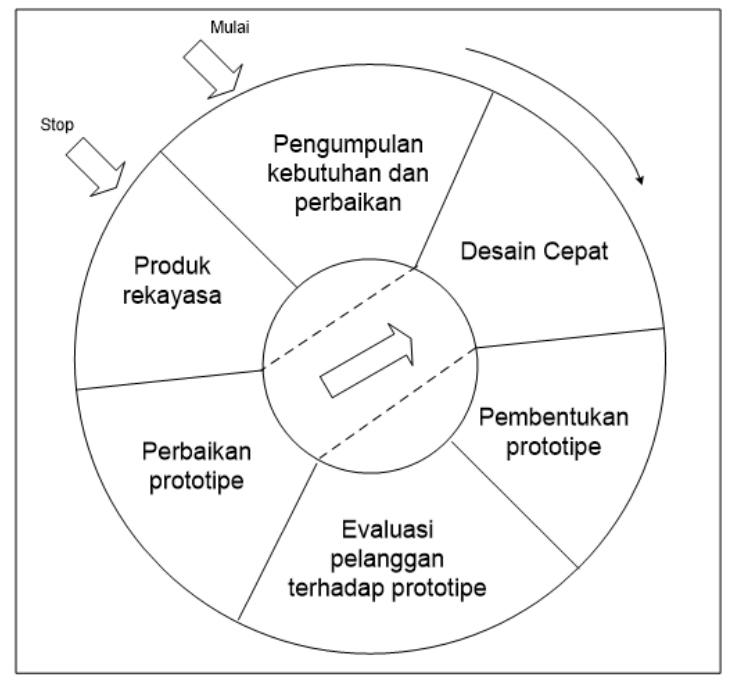

Gambar 1 Diagram Pengembangan Perangkat Lunak

Sesuai dengan mekanisme penelitian yang diilustrasikan pada gambar diatas, langkah utama dalam penelitian ini dapat diuraikan sebagai berikut. 1) Tahap pengumpulan kebutuhan dan perbaikan. Pada tahap ini dilakukan pengumpulan data yang dibutuhkan untuk pengembangan sistem backup database otomatis pada sistem informasi Perpustakaan Undiksha dengan metode backup penuh (full backup) dan backup file web otomatis pada sistem informasi Perpustakaan Undiksha dengan metode cermin (mirror backup). Data yang dikumpulkan berupa informasi kebutuhan perangkat lunak dan perangkat keras pendukung. Data diperoleh dengan teknik observasi dan pengumpulan informasi kebutuhan perangkat lunak dan perangkat keras dilakukan dengan studi literatur. Data yang dikumpulkan dianalisis untuk mendapatkan algoritma untuk pengembangan sistem, sedangkan informasi perangkat 
lunak dan perangkat keras pendukung dianalisis untuk mendapatkan komposisi perangkat lunak dan perangkat keras yang ideal untuk mendukung pengembangan sistem database backup otomatis dan terjadwal. 2) Tahap perancangan desain cepat (desain awal) Algoritma yang telah tersusun pada tahap sebelumnya dipergunakan untuk merancang desain awal dari produk yang akan dibangun yang biasanya masih bersifat global. Untuk langkah awal, perancangan desain cepat terutama dapat dilakukan pada rancangan proses backup data. 3) Tahap membangun prototipe. Berdasarkan desain awal yang telah ditetapkan maka mulai dilakukan pengimplementasian untuk memperoleh produk yang diharapkan. Pekerjaan pada tahap ini belum menyentuh aspek detai dari perangkat lunak yang dibangun. Tujuan pembangunan prototype untuk mempermudah proses dari perangkat lunak yang dibangun. Ada 3 jenis prototipe yaitu: prototipe di atas kertas. prototipe kerja, yaitu prototipe yang telah diimplementasikan ke dalam bahasa pemrograman, sehingga dapat dieksekusi namun belum berjalan sempurna; dan prototipe jadi, yaitu prototipe yang telah jadi tapi mungkin masih perlu disesuaikan dengan kebutuhan pengguna. 4) Tahap evaluasi prototipe. Pada tahap ini dapat dilakukan evaluasi terhadap prototipe yang dihasilkan sehingga produk akhir semakin bagus dan kemungkinan kesalahan produk semakin kecil. Evaluasi dilakukan dengan melibatkan pakar TIK dan pemakai sistem. 5) Tahap perbaikan prototipe. Berdasarkan evaluasi oleh pengguna jika telah sesuai dengan yang diharapkan maka tahapan dilanjutkan ke rekayasa produk. Jika ada kesalahan maka akan diperbaiki, sesuai tkita panah dalam diagram, langkah pengerjaan kembali lagi pada langkah desain cepat dan seterusnya hingga prototipe tersebut sesuai dengan yang diharapkan. 6) Tahap rekayasa produk. Pada tahap inilah sistem database backup otomatis dan terjadwal benar-benar telah diimplementasikan hingga diperoleh hasil akhir yang siap digunakan.

Pada penelitian ini akan menggunakan Perpustakaan Universitas Pendidikan Ganesha sebagai studi kasus. Purposive sampel akan menggunakan server Perpustakaan Universitas Pendidikan Ganesha. Prosedur Pengumpulan dan Pengolahan Data Instrumen pengumpulan data yang digunakan pada penelitian ini, terdiri dari beberapa instrumen yaitu: (1) pedoman observasi, (2) kuisioner, (3) pedoman wawancara, (4) studi dokumentasi, dan (6) expert judgement.

\section{HASIL PENELITIAN DAN PEMBAHASAN}

Secara umum penelitian ini akan melakukan duplikasi database sistem perpustakaan dalam bentuk file dengan ektenssion *.sql. proses duplikasi akan dilakukan setiap hari secara otomatis dan akan tersimpan dalam drive server. Setelah file hasil backup tersimpan dalam server local selanjutnya akan di kirim ke server backup yang ada di kampus Undiksha Jineng Dalem dengan menggunakan jaringan VPN (Virtual Private Network). Untuk mengantisipasi penuhnya media penyimpanan di server local, maka akan dilakukan penghapusan file 30 hari terakhir secara otomatis dengan script bash pada linux. Untuk lebih jelasnya alur dari penelitian ini dapat di gambarkan pada gambar di bawah ini. 


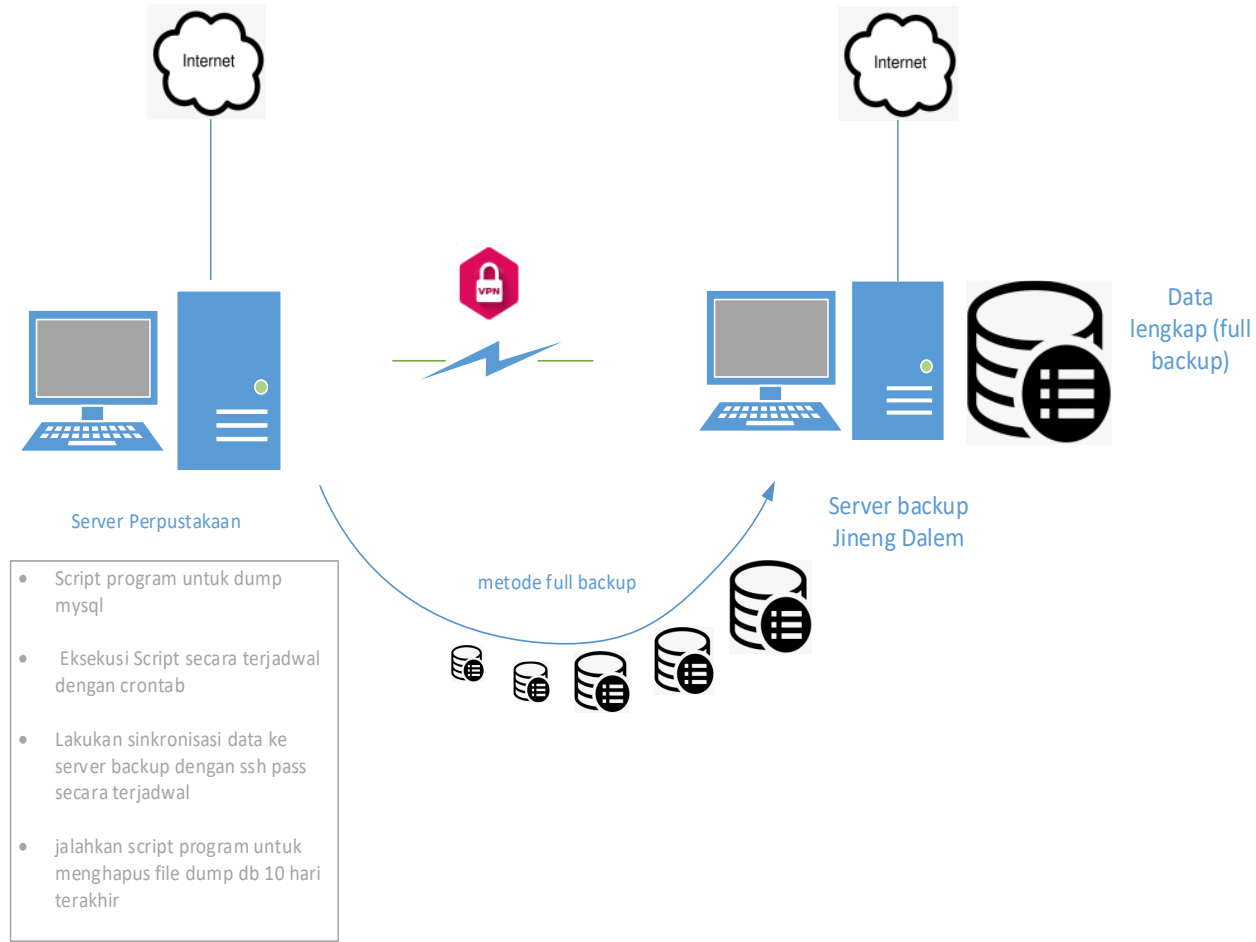

Gambar 2. Gambaran umum sistem

Untuk menggunakan bash, Kita harus terhubung ke server VPS terlebih dulu melalui SSH. Setelah berhasil masuk ke server VPS, Kita siap untuk menjelajahi penggunaan bash function Linux. Script bash linux dapat kita buat dengan editor yang tersedia pada sistem operasi linux yang digunakan, berikut adalah hasil dari script bash yang yang ditulis pada editor pico. Berikut adalah potongan scriptnya

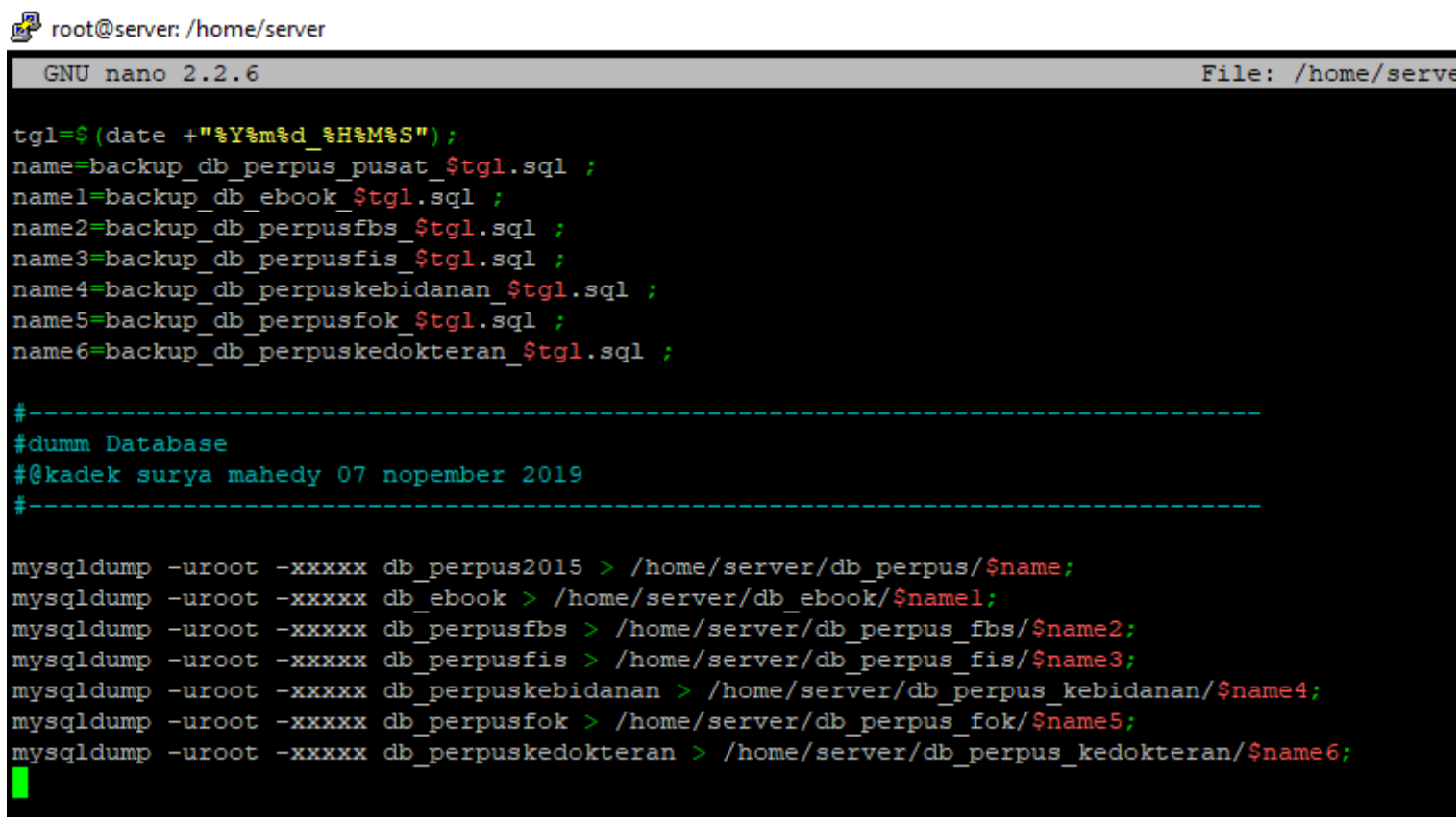

Gambar 3. Script bash untuk dummy data pada mysql

script diatas akan menghasilkan file *.sql dengan nama masing-masing database disertai dengan tanggal saat database di dumping, dengan penamaan file seprti ini akan 
sangat membantu untuk mengidentifikasi file hasil backup yang tersiman dalam drive, script ini akan dieksekusi setiap hari secara otomatis dengan memanfaatkan fitur Crontab yang ada pada sistem operasi linux Ubuntu. Untuk menghindari penuhnya kapasistas penyimpanan yang ada pada server perpustakaan, kita akan tambahkan script untuk menghapus file backup 30 hari terakhir secara otomatis, berikut adalah script penghapusan file backup yang sudah di buat lebih dari 30 hari, berikut adalah script untuk menghapus hasil backup yang telah dibuat lebih dari 30 hari.

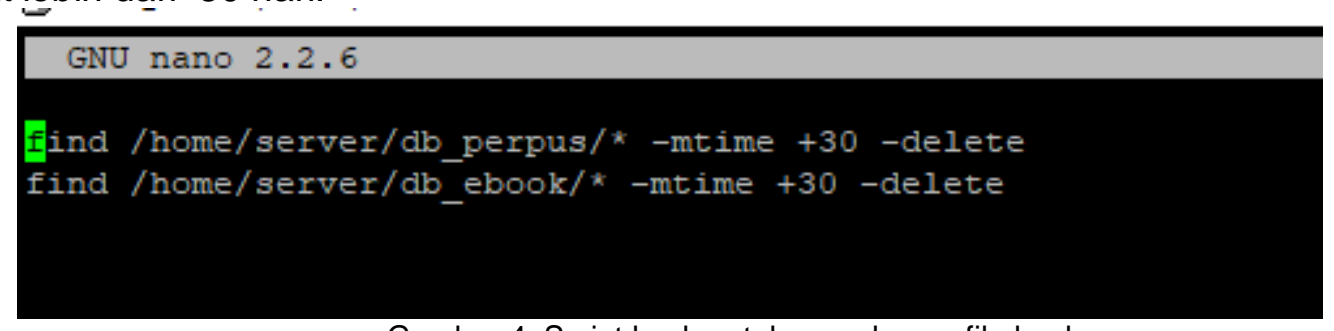

Gambar 4. Script bash untuk menghapus file backup

File backup tidak hanya tersimpan pada server lokal akan tetapi hasil backup setiap hari akan di kirim ke server backup yang berada di kampus Jineng Dalem, proses pengiriman file backup akan menggunakan jaringan VPN, jaringan VPN ini akan memberikan jalur akses dengan SSH yang bekerja pada port 22. Sebelum data hasil dummy mysql dipindahkan ke server backup kita harus sediakan jaringan VPN terlebih dalulu, berikut adalah gambaran jaringan VPN antara server perpustakaan dengan server backup yang ada di Jineng dalem.

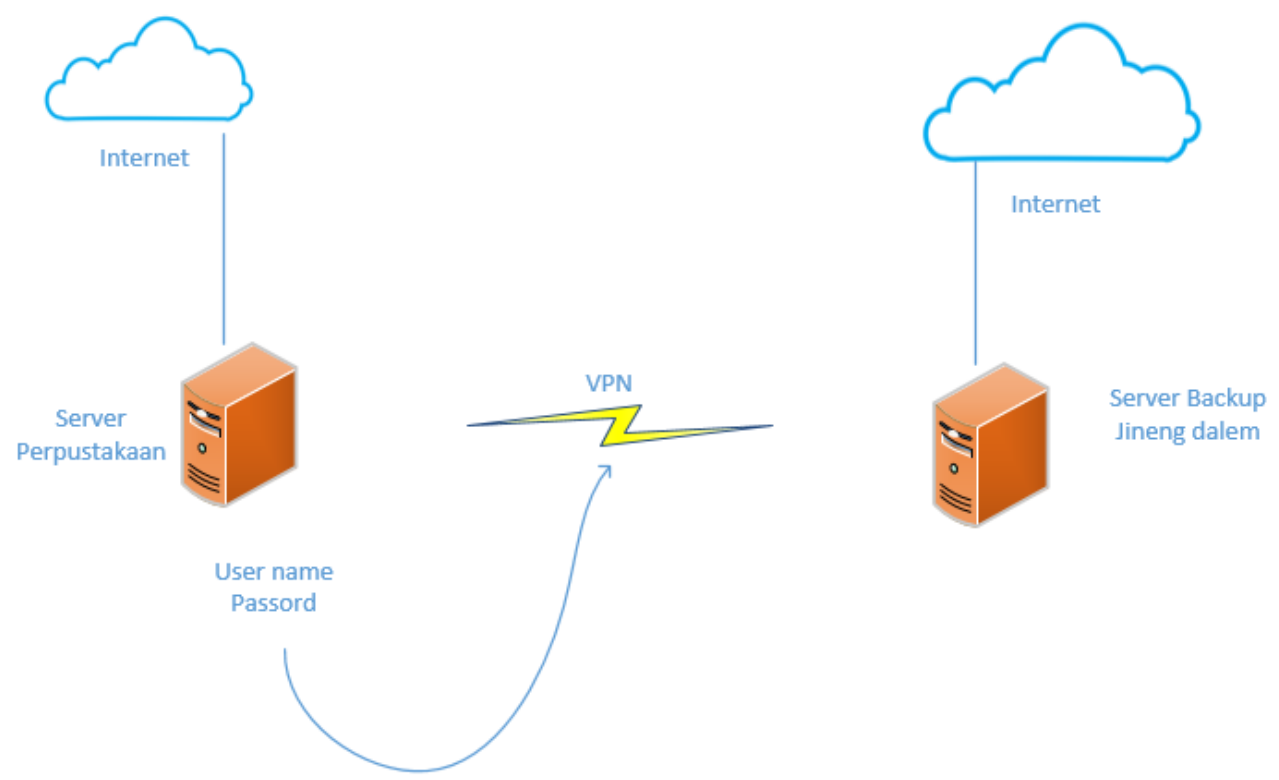

Gambar 5. Jaringan VPN

Dengan menggunakan user name dan password yang sudah di konfigurasi, server perpustakaan akan terkoneksi dengan jaringan VPN, sehingga dari server perpustakaan dan server backup seolah-olah menjadi satu jaringan local. Dengan terhubungnya kedua server menjadi satu jaringan makan proses sinkronisasi data sudah dapat dilakukan oleh kedua buah server. proses sinkronisasi file antar server dapat dilakukan dengan menggunakan rsync, rsync adalah sebuah fitur transfer file antar server dengan menggunkan ssh, berikut adalah srcript untuk sikronisasi data dari server perpustakaan dengan server backup. rsync -e ssh av -P-z/home/server-jd@192.168.10.102:/home/backup/db_perpus. 
Semua proses mulai dari dumping data mysql sampai dengan proses sinkronisasi akan dilakukan secara terjadwal dengan fitur crontab yang sudah tersedia pada sistem operasi linux ubuntu. Berikut adalah script untuk membuat jadwal dumping data dan sinkronisasi data secara terjadwal dengan crontab.

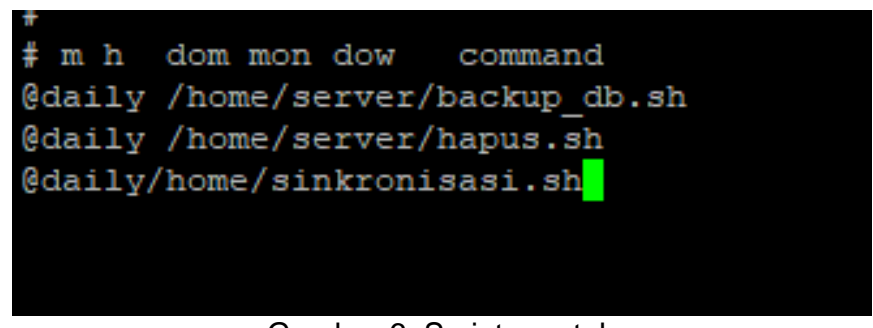

Gambar 6. Script crontab

Masing-masing script bash yang kita buat akan disimpan dengan extention *.sh, seperti dalam penelitian ini, script untuk dumping data mysql akan disimpan dengan nama backup_db.sh, sedangkan script untuk menghapus data yang sudah berumur 30 hari akan diberi nama hapus.sh, dan script untuk sinkronisasi data ke server backup diberi nama sinkronisasi.sh. untuk backup file web akan dilakukan dengan menggunakan metode cermin akan diimplementasikan dengan melakukan configurasi ssh terlebh dahulu. SSH merupakan singkatan dari Secure Shell. SSH merupakan jaringan protokol open source yang dapat digunakan untuk login ke server dan mengeksekusi command jarak jauh. Hal tersebut sangat membantu VPS user. Sedangkan SCP (Secure Copy Protocol), yang mana berbasis SSH, dapat digunakan untuk menyalin file dari satu komputer ke komputer lain. Pada implementasi penelitian ini, kita akan membahas bagaimana cara setup ssh tanpa password pada Linux. Ada dua cara untuk mengaktifkan SSH yaitu password-based authentication dan public key based authentication.

Pada implementasi penelitian ini, kita akan fokus pada SSH yang kedua (public key based authentication) yang mana versi ini merupakan versi terbaru dan protokolnya lebih aman. Untuk memulai setting SSH, kita harus login ke server VPS melalui SSH terlebih dahulu. Pertama, kita cek apakah SSH key untuk perangkat client sudah tersedia, langkah ini akan mencegah penumpukan konfigurasi yang ada. Kita dapat menggunakan command dibawah ini untuk mengetahuinya:

\section{Is -al /.ssh/id_*.pub}

Jika key nya sudah ada, maka kita dapat melewati langkah pembuatan SSH key, override setup yang ada, atau kita dapat membuat backup untuk key yang ada. Jika tidak ada SSH key yang didapati, kita akan melihat output berikut:

Is: cannot access /users/appsadm/.ssh/id_* .pub: No such file or directory

Untuk membuat key public maupun private pada Ubuntu, dapat kita gunakan command seperti berikut:

\section{ssh-keygen -t rsa}

Opsi -t merupakan opsi untuk type (tipe), sedangkan RSA adalah protokol yang digunakan untuk membuat private key. RSA merupakan tipe default kita dapat menggunakan versi yang lebih sederhana yaitu - ssh-keygen. Value dari default key adalah 2048 bits. Tetapi, jika kita memerlukan keamanan yang lebih kuat, kita dapat mengganti valuenya ke 4096 bits. Pada kasus ini, kita dapat menggunakan command seperti berikut:

\section{ssh-keygen -t rsa -b 4096}

Proses ini merupakan interactive key generation process dimana kita akan mendapatkan beberapa pertanyaan seperti, masuk ke file untuk menyimpan key (/home/.ssh.id_rsa) dan masukkan passphrase (biarkan kosong bila tidak ada paraphrase). kita dapat menekan enter untuk kedua pertanyaan ini. Jika kita tekan enter untuk keduanya maka proses ini akan mengambil value default. Paraphrase digunakan untuk mengenkripsi private key; tetapi, proses ini tidak wajib dan dapat dibiarkan kosong. Private key akan disimpan di lokasi default -.ssh/id_rsa. Sedangkan public key akan disimpan di dalam file .ssh/id_rsa.pub. Setelah itu, 
kita dapat memverifikasi file dengan menggunakan editor apa pun. Untuk menyalin public key ke perangkat yang dituju dapat dilakukan dengan tiga cara:

1. Menggunakan command ssh-copy-id

2. Menyalin public key menggunakan SSH

3. Menyalin public key secara manual

Opsi pertama merupakan yang paling direkomendasikan dan yang tercepat. Command sshcopy-id secara default telah berada pada sistem variasi Linux. Namun, pada beberapa instance, kita akan menghadapi isu berkaitan dengan ssh-copy-id atau bahkan sama sekali tidak memiliki akses atas command ini. Untuk permasalahan itu, kita dapat menggunakan opsi subsequent.

Metode 1: Menggunakan Command ssh-copy-id

Basic syntax untuk menggunakan command ini adalah seperti yang ditunjukkan di bawah: ssh-copy-id remote_username@remote_IP_Address

Di sini kita akan mendapatkan prompt untuk kata sandi perangkat yang kita remot. Setelah otentikasi berhasil, public key SSH yang dihasilkan akan ditambahkan ke file otor_keys dari perangkat remote. Setelah Kita menambahkan entri, koneksi akan ditutup secara otomatis.

\section{Metode 2: Menyalin public key menggunakan SSH}

Metode selanjutnya adalah menggunakan SSH untuk menyalin private key. Metode ini dapat digunakan ketika kita memiliki akses SSH berbasis password pada server. Command di bawah ini akan menjalankan prosesnya. Kita hanya perlu memasukkan username dari user dan alamat IP perangkat.

cat $\sim / . s s h / i d \_r s a . p u b \mid$ ssh remote_username@remote_ip_address "mkdir -p /.ssh \&\& cat $>\sim /$ ssh/authorized_keys"

Command ini akan menambahkan entri ke file authorized_key di perangkat remote.

Metode 3: Menyalin Public Key Secara Manual

Jika ada masalah dengan metode-metode sebelumnya, Kita dapat menggunakan metode ini. Namun, metode ketiga ini agak lebih sulit karena seluruhnya dilakukan secara manual. Kita secara manual perlu menambahkan isi file id_rsa.pub ke file server

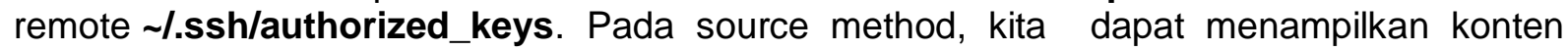
file id_rsa.pub dengan menggunakan editor pico atau command cat:

cat $\sim /$.ssh/id_rsa.pub

Command ini akan menampilkan output yang berisi key, yang mana key tersebut dimulai dengan ssh-rsa. Selanjutnya, kita perlu untuk menyalin kode tersebut. Setelah itu, login pada remote server dan buatlah file .ssh jika file nya tidak ada.

mkdir - p /.ssh

kita juga dapat membuat file authorized_key dengan cara yang sama. Tambahkan public key SSH ke file yang kosong seperti yang ditunjukkan di bawah ini:

echo SSH_public_key >> /.ssh/authorized_keys

SSH_public_key menjadi public key yang kita salin dari perangkat sumber ssh-rsa. Setelah key disalin, kita dapat mempersiapkan permission yang dibutuhkan direktori .ssh pada server remote dengan menggunakan command chmod.

chmod $-766 \sim /$ ssh

\section{Menguji SSH Tanpa Password}

Dengan melakukan langkah-langkah di atas, seharusnya Kita berhasil mengaktifkan SSH tanpa password dan siap melakukan konfigurasi dasar. Untuk menguji fiturnya, Kita dapat mengakses server remote melalui server source. Command syntax tersebut akan terlihat seperti ini:

\section{ssh remote_username@remote_IP_Address}

Jika semua bekerja dengan baik, kita dapat masuk secara otomatis tanpa harus memasukkan password. Jika kita merasa bahwa kita tidak lagi nyaman dengan SSH tanpa password, kita dapat mematikan fiturnya dengan beberapa langkah. Untuk melakukannya, kita perlu membuka file konfigurasi SSH - /etc/ssh/ssh_config. kita dapat menggunakan editor apapun. Pada contoh ini, kita menggunakan pico. Disini, kita dapat menemukan entri dengan PasswordAuthentication. Modifikasi barisannya seperti berikut: 


\section{PasswordAuthentication no ChallengeResponseAuthentication no UsePAM no}

Setelah diubah, simpan file dan restart SSH Kita dengan command sebagai berikut sudo systemctl restart ssh

Dalam penelitian ini transfer data dengan SSH akan dilakukan secara otomatis dengan fitur Crontab yang sudah tersedia pada sistem operasi Linux Ubuntu, berikut adalah script untuk melakukan transfer file dengan SSH:

rsync -e ssh -av -P -z /home/ server-jd@192.168.10.102:/home/backup/db_perpus. Berikut adalah hasil uji coba sstem backup data pada sistem informasi perpustakaan Universitas Pendidikan Ganehsa.

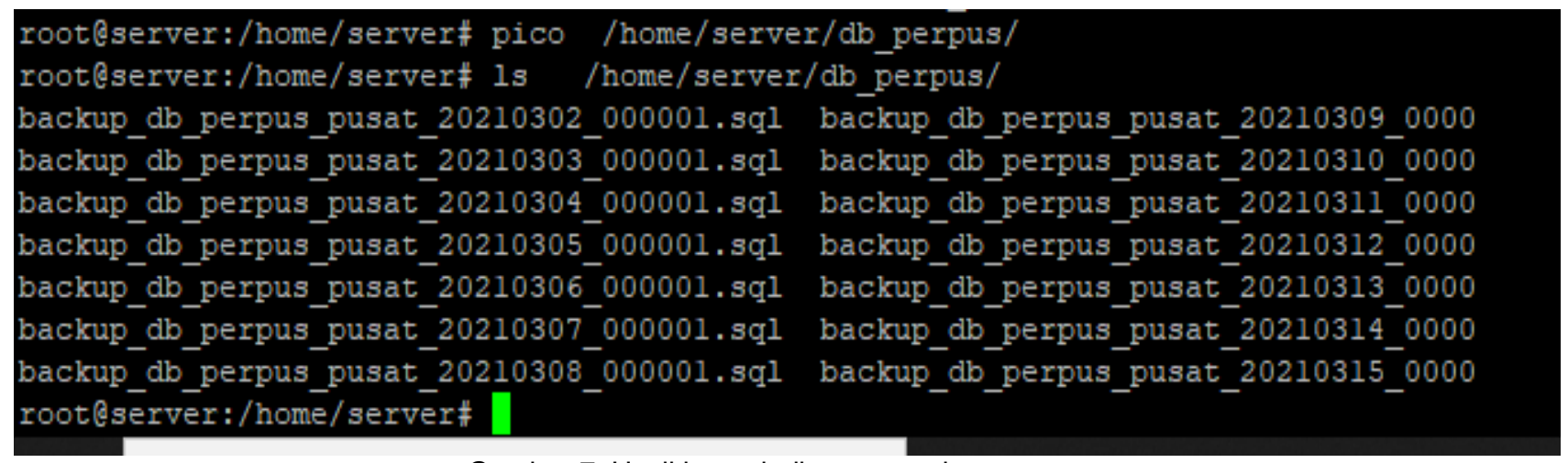

Gambar 7. Hasil bacupk db_perpustakaan

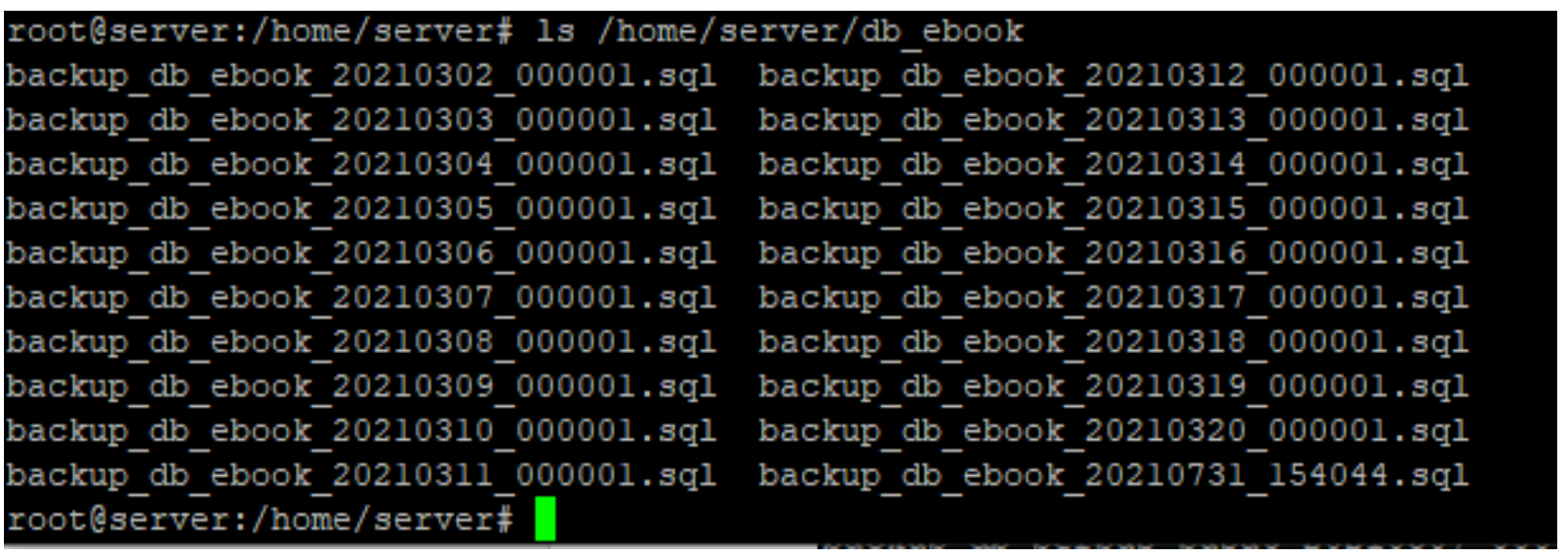

Gambar 8. Hasil bacupk db_ebook

Dari gambar 7 dan 8 terdapat file hasil backup system perpustakaan dan system buku elektronik (ebook)selama 14 hari terakhir. Backup otomatis dilakukan dari hari senin sampai jumat setiap jam 00.00 wita.

\section{SIMPULAN DAN SARAN}

Berdasarkan hasil dan pembahasan dapat disimpulkan bahwa sistem ini dapat digunakan sebagai fitur untuk melakukan backup data secara terjadwal dan otomatis yang dilakukan oleh sistem, dengan sistem ini diharapkan dapat memeberikan kemudahan dan kenyamanan kepada pemakai sistem dalam hal ini sistem informasi perpustakaan Universitas Pendidikan Ganesha. Dengan dikembangkannya sistem ini akan dapat meminimalisasi terjadinya kehilangan data yang disebabkan oleh kerusakan perangkat atau kelalaian user, 
karena semua data akan diduplikasi dan disimpan pada server yang berbeda. Jika terjadi kehilangan data makan user dapat mengembalikan data dari server cadangan.

Untuk meningkatkan keamanan data, sistem ini perlu di integrasikan untuk sistemsistem yang ada di Universitas Pendidikan Ganesha, dengan demikian semua sistem akan memiliki data cadangan yang akan tersimpan di server cadangan.

\section{DAFTAR PUSTAKA}

[1] Andry, "Pengembangan Aplikasi Backup Dan Restore Secara Automatisasi Menggunakan Sdlc Untuk Mencegah Bencana", Jurnal Muara, Vol 1, No 1 (2017).

[2] Andry, J. F. \& Loisa, J. "The e-Commerce Potential for Home-Based Businesses: A Case Study," Jurnal IImiah FIFO P-ISSN 2085-4315 / E-ISSN 2502-8332, Volume VIII, No. 2, 23-27, 2016.

[3] Andry, J. F., Agung, H. \& Erlyana, Y, "Management Information System for Order Fulfillment: A Case Study", Proceeding of 9th International Seminar on Industrial Engineering and Management, ISSN : 1978-774X, 2016

[4] Arhami M, "Bahan Kuliah Pertemuan 10 Rekayasa Perangkat Lunak Data Flow Diagram (DFD) dan Kamus Data", Tersedia pada http://arhami.files.wordpress.com/2011/08/bahan-kuliah_dfd.pdf(diaksestanggal 20 juni 2013),

[5] Bafadal Ibrahim, Pengelolaan Perpustakaan Sekolah. Jakarta: Bumi Aksara, 2005.

[6] Darmono, Perpustakaan Sekolah Pendekatan Aspek Manajemen dan Tata Kerja. Jakarta: Grasindo, 2016.

[7] Elyyani, "Metode Manajemen Backup Data Sebagai Upaya Penyelamatan Data Online Web Lapan Bandung", Jurnal Sains dan Teknologi, Volume 13 Nomor 1(22-27),2016.

[8] Harif, M, Membangun Database Berbasis Open Office dan MySQL. Jakarta: Dian Rakyat, 2004.

[9] Fernandes, Johanes. "Using Backup and Restore Automation from Disaster in University Information System" . Prosiding ICIRAD. 2017

[10] Hoong, L, L., \& Marthandan, G. "Critical Dimensions of Disaster Recovery Planning", International Journal of Business and Management, Vol. 9, No. 12, ISSN 1833-3850, EISSN 1833-8119, Published by Canadian Center of Science and Education, 145-158. 2014

[11] Mishra, A. \& Dubey, D. "A Comparative Study of Different Software Development Life Cycle Models in Different Scenarios". International Journal of Advance Research in Computer Science and Management Studies, ISSN: 2321-7782 (Online), Volume 1, Issue 5, 64-69. 2013.

[12] Suprianto, Unified Modeling Language, Yogyakarta: ANDI,. 2005.

[13] S. Indra. Membangun Infrastruktur Komputasi Awan Privat Menggunakan Ubuntu Enterprise Cloud: Andi Yogyakarta. 2012. 